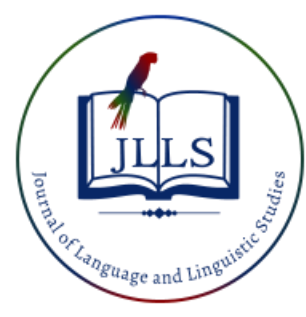

Available online at www.jlls.org

JOURNAL OF LANGUAGE AND LINGUISTIC STUDIES

ISSN: $1305-578 \mathrm{X}$

Journal of Language and Linguistic Studies, 16(3), 1177-1188; 2020

\title{
The impact of L1 interference on foreign language writing: A contrastive error analysis
}

\author{
Semin Kazazoğlu a 1 iD \\ ${ }^{a}$ Ylldız Teknik Üniversitesi, İstanbul, Turkey
}

\section{APA Citation:}

Kazazoğlu, Semin. (2020). The Impact of L1 Interference on Foreign Language Writing: A Contrastive Analysis. Journal of Language and Linguistic Studies, 16(3), 1177-1188.

Submission Date: 02/03/2020

Acceptance Date:17/06/2020

\begin{abstract}
In today's world, educational contexts are getting increasingly multicultural. Although EFL (English as a Foreign Language) classes in Turkey were mostly composed of Turkish students a decade ago, today students from any part of the world are brought together within the frame of various student exchange programs. In Turkish EFL contexts, students coming from Middle Eastern countries make up a huge part of classes (Özer, 2016). The objective of the current study is to examine L1 negative interference errors of Turkish and Arabic EFL learners. Accordingly, 30 B1 (Intermediate) EFL students' written assignments were examined and divided into categories. Besides, this study makes a comparative analysis of Turkish and Arabic EFL learners' grammatical and lexical errors within the frame of L1 negative transfer. When the results of the Mann-Whitney U test are analyzed, it is understood that Turkish and Arabic students' grammatical interference exam scores differ statistically ( $<<0.05$ ). When the total amount of errors is analyzed, Turkish students' grammar errors ( $\mathrm{n}=164)$ stem from, majority of which are articles, preposition and tense errors, respectively as $18.82 \%, 17.65 \%$ and 11.76 whilst Arabic students make a huge part of their errors $(\mathrm{n}=352)$ on capitalization, punctuation and tenses/articles, respectively as $16.19 \%$, $15.06 \%$, and $12.78 \%$. In the frame of the lexical category, Turkish students performed 48 lexical errors, the majority of which are spelling and collocation errors. On the other hand, Arabic students committed 96 lexical errors in total, the majority of which are spelling errors $(60.4 \%)$ while $15.5 \%$ of the errors are wrong word choice. In general, lexical errors were fewer than grammatical errors.
\end{abstract}

(C) 2020 JLLS and the Authors - Published by JLLS.

Keywords: L1 interference; Contrastive error analysis; Turkish EFL Learners; Arabic EFL Learners; Applied Linguistics

\section{Introduction}

To understand the basis of the L1 effect on L2, it is vital to analyze the language learning theories that define how L1 affects the acquisition process of L2 and the source of learners' errors. Richards and Schmidt (2002, p. 184) state that error analysis is the study of errors committed by L2 learners, intending to understand the reasons for these errors Gass and Selinker (2008, p. 103) identify two error types as

\footnotetext{
${ }^{1}$ Corresponding author. Tel.:

E-mail address: seminkazazoglu@gmail.com
} 
'interlingual' and 'intralingual' errors. Interlingual errors are caused by learners' native language and the target language can lead to intralingual errors.

Likewise, Ellis (2006, p. 174) states that new experiences can interfere with earlier memories, so the impact of prior learning limits new learning. He also points out that there can be difficulty in remembering previous information because of new information. Brown (2007) firmly states that second language learning is affected by the negative effect of learners' mother tongue and he puts forward that overgeneralization is a negative intralingual transfer because it appears when using target language rules incorrectly. Burt (1975) defines two types of errors as 'global' and 'local'. The errors in the general structure of the sentence hindering the communication are global whereas the errors that do not have any effect on the meaning are local.

\subsection{Literature review}

Nunan (2001) puts forward that when the rules governing the two languages are different, the errors appear due to the interference between two languages. Furthermore, he claims that the more similar the two languages, the fewer mistakes learner do, which refers to positive transfer. If the rate of similarity is less, then there is negative transfer and in this case, L2 learners use the structures that they know in their mother tongue and a high amount of errors are expected to happen (Ellis, 1997; Richard \& Schmidt, 2002). Likewise, Jie (2008) defines transfer as "the carrying-over of learned responses from one type of situation to another. The transfer can be divided into two as positive transfer and negative transfer. The positive transfer is using rules from L1 that reflect positively on learning L2 due to the similarities between the two languages. However, the negative transfer is the transfer of rules from L1 that affects the learning process of L2 negatively because of the differences between L1 and L2"' (p.1).

The contrastive analysis which is the systematic comparison of two or more languages aims to point out differences and similarities. When the two languages are not similar, learners will employ the patterns in their mother tongue to enable them to do tasks in learning L2 (Johansson, 2008).

\subsubsection{Differences between English and Turkish Language}

Turkish language, belonging to the Ural-Altaic family, has 29 letters and eight of them are vowels, which are a, e, 1, i, o, ö, u, ü. Turkish words are spelled as they are spoken. Pierce (2009) makes a summary of the differences between English and Turkish, which is also applicable to the experiences of Turkish learners who learn English as a second language. Pierce (2009) states that since in Turkish there is no gender-based pronoun, even the most proficient Turkish learners confuse "he" and "she". Another area of confusion can stem from the use of Turkish use of interrogatives as "kim, ne, neden", which act as rudimentary relatives as well. Ne zaman gelecekler bilmiyorum in English I don't know when they will come is: "What time come-will-they know-not-I" (Pierce, 2009). Accordingly, when Turkish learners apply for the word order in Turkish into the English language, many transference errors can appear.

Some studies are pointing out the interference errors made by Turkish EFL learners. In a study by Kırkgöz (2010), it is found that EFL learners have more interlingual errors than intralingual errors. By examining 120 compositions that were written by EFL learners, Kırkgöz (2010) concluded that learners who are at the beginning of their language learning process make more mistakes than the learners who are at the higher levels of language learning due to the negative transfer. She defines errors like grammar, preposition, and lexis under the title of inter-lingual errors and errors such as overgeneralization, using articles incorrectly, and spelling as the intra-lingual errors. Besides, in a study of Erkaya (2012) 17 Turkish EFL learners mostly make wrong word choice, article, preposition, punctuation, and singular plural errors all of which all stem L1 interference. Likewise, Elk1lıc (2012) analyzed 1078 written papers 
of Turkish intermediate and upper-intermediate learners and identified common errors in the categories of translation, preposition, article, and uncountable nouns.

\subsubsection{Differences between English and Arabic Language}

As Hamdallah and Tushyeh (1993) point out, different family groups that English and Arabic languages belong to is the basis of the difference. Learners whose mother tongue is Arabic belonging to the Semitic language family are expected to make mistakes when learning English, which is in the IndoEuropean language family. Ali (2007) puts forward that '"while English has 26 letters, Arabic has 28 eight letters, and "Hamza" the glottal stop can be accepted as the twenty-ninth letter. Another important area of difference is that while there is a difference between upper case and lower case letters in English, there is no distinction between them in Arabic. Moreover, English is written from left to right and Arabic is written from right to left" (p.4). Therefore, the huge difference between these two languages can cause negative transfer (Nunan, 2001, p. 89). Besides, they can refer back to Arabic in cases of unclarity when learning English (Johansson, 2008). According to Ehri and Rosenthal (2010), a good command of spelling makes language learners state their ideas conveniently and clearly while writing. The most frequent errors Arab learners make when they write in English are the inclusion of final [e], vowels, silent letters, and double consonants (Rohman, 2017).

\subsection{Research questions}

1. What are the major lexical and grammatical errors of EFL Turkish and Arabic students?

2. What types of lexical and grammatical errors are common in Turkish and Arabic EFL students' writings?

3. What are the common errors that stem from L1 negative interference?

\section{Method}

The analysis of the study consists of three parts. Firstly, Error Analysis has been used to gather a general perspective on the topic. Accordingly, a total of 30 English essay papers have been examined and errors have been identified and categorized. Then, the number of errors were counted and framed. Lastly, the Mann-Whitney U test has been conducted to identify the differences between the two of the groups.

\subsection{Sample / Participants}

The participants of the study are 30 Intermediate students (15 of whom are Arabic students and the rest of 15 are Turkish students) studying EFL at a private university in İstanbul, Turkey. Turkish students who are all 18 years old stated that it is the first time they are exposed to such an intensive language learning program although they have been learning English at least for 7 years.

Students whose L1 is Arabic are from different parts of the Middle East. 8 of them are from Syria, 4 of them are from Palestine, 3 of them are from Egypt. While 12 of them are 18 years old, 2 of them are 19 and one of them is 20.10 of these students stated that they have been learning English for 4 years and the rest stated that they have been exposed to the English language for 3 years or less. While 10 of these students stated that they have been in Turkey for 2 years, 5 of them stated that they have been living in Turkey for 6 months. Like Turkish students, Arabic students have also stated that they haven't been exposed to such an intensive language learning program before. 


\subsection{Instrument $(s)$}

The instrument of the study is a corpus of Turkish and Arabic B1 level students' writing exam papers

\subsection{Data Collection Procedures}

To learn about the effect of L1 on B1 level students' L2, the participants' writing exam papers were analyzed. Students' errors were divided into lexical and grammatical categories. Each type of error was underlined and checked whether it was due to the effect of negative transfer by checking the previous literature. Students' final papers were graded in line with the writing criteria of the university. Students' overall grades in the exams were also analyzed to understand how L1 interference affects their writing grades. Before the study, students were informed about the evaluation of their papers in terms of the L1 effect. Finally, the Mann-Whitney U test was conducted in order to identify the differences between the Turkish and Arabic students' lexical and grammatical errors.

\section{Results}

The findings were presented with regard to the research questions.

\subsection{What types of grammatical errors are common in Turkish EFL students' writings?}

The results reveal that the highest number of grammatical errors constitutes article (\%18.82) and preposition (\%17.65) errors. This finding correlates with the study in which Köroğlu (2014) defines articles and prepositions as the most problematic total of errors committed by Turkish students learning English as a foreign language. Similarly, Taşçı and Aksu Ataç (2018) put forward that Turkish EFL students don't use prepositions in English essays for the verbs which don't require preposition in Turkish equivalent. Furthermore, they correlated this finding with L1 negative transfer.

Table 1. Grammatical Interference Errors in Turkish EFL Students’ Writings

\begin{tabular}{|c|c|c|c|c|}
\hline $\begin{array}{l}\text { Grammatical } \\
\text { Interference }\end{array}$ & Example & The correct form & $\begin{array}{r}\text { The number } \\
\text { of errors }\end{array}$ & $\begin{array}{c}\text { Percent } \\
\%\end{array}$ \\
\hline 1. Pronoun mistakes & $\begin{array}{c}\text { People should make theirs } \\
\text { own choices. }\end{array}$ & $\begin{array}{c}\text { People should make their } \\
\text { own choices. }\end{array}$ & 15 & 8.82 \\
\hline $\begin{array}{c}\text { 2. Singular/Plural } \\
\text { errors. }\end{array}$ & $\begin{array}{c}\text { Most of this people live in } \\
\text { the city. }\end{array}$ & $\begin{array}{c}\text { Most of these people live in } \\
\text { the city. }\end{array}$ & 15 & 8.82 \\
\hline 3. Article errors & Children can play in park & $\begin{array}{c}\text { Children can play in the } \\
\text { park. }\end{array}$ & 32 & 18.82 \\
\hline $\begin{array}{l}\text { Countable } \\
\text { \&Uncountable } \\
\text { errors }\end{array}$ & Money are important. & Money is important. & 5 & 2.94 \\
\hline 5. Prepositions errors & $\begin{array}{c}\text { They are responsible from } \\
\text { them. }\end{array}$ & $\begin{array}{c}\text { They are responsible for } \\
\text { them. }\end{array}$ & 30 & 17.65 \\
\hline $\begin{array}{c}\text { Adjective\&Adverb } \\
\text { errors }\end{array}$ & $\begin{array}{c}\text { They want to buy cheaply } \\
\text { products. }\end{array}$ & $\begin{array}{c}\text { They want to buy cheap } \\
\text { products. }\end{array}$ & 7 & 4.12 \\
\hline 7. Tense errors & $\begin{array}{c}\text { People are happier in the } \\
\text { past. }\end{array}$ & $\begin{array}{c}\text { People were happier in the } \\
\text { past. }\end{array}$ & 20 & 11.76 \\
\hline 8. Word Order errors & $\begin{array}{c}\text { Students wake up often } \\
\text { late. }\end{array}$ & $\begin{array}{c}\text { Students often wake up } \\
\text { late. }\end{array}$ & 7 & 4.12 \\
\hline $\begin{array}{c}\text { 9. Relative Clause } \\
\text { errors }\end{array}$ & $\begin{array}{c}\text { People who want to live in } \\
\text { a city they have many } \\
\text { problems. }\end{array}$ & $\begin{array}{c}\text { People who want to live in } \\
\text { a city have many } \\
\text { problems. }\end{array}$ & 10 & 5.88 \\
\hline $\begin{array}{c}\text { 10. Comparative } \\
\text { /Superlative errors }\end{array}$ & $\begin{array}{c}\text { People have most problems } \\
\text { in a big city than a } \\
\text { village. }\end{array}$ & $\begin{array}{c}\text { People have more problems } \\
\text { in a big city than a } \\
\text { village. }\end{array}$ & 8 & 4.71 \\
\hline 11. Punctuation errors & $\begin{array}{c}\text { People want to have a good } \\
\text { education so they } \\
\text { move live in big cities. }\end{array}$ & $\begin{array}{c}\text { People want to have a good } \\
\text { education, so they } \\
\text { move live in big cities. }\end{array}$ & 15 & 8.82 \\
\hline $\begin{array}{c}\text { 12. Capitalization } \\
\text { errors }\end{array}$ & $\begin{array}{l}i \text { think we should spend } \\
\text { more time on hobbies }\end{array}$ & $\begin{array}{l}I \text { think we should spend } \\
\text { more time on hobbies }\end{array}$ & 6 & 3.53 \\
\hline
\end{tabular}




\subsection{What types of lexical errors are common in Turkish EFL students' writings?}

Table 2. Lexical Interference Errors in Turkish EFL Students' Writings

\begin{tabular}{|l|l|l|l|l|}
\hline Lexical Interference & Example & The correct form & $\begin{array}{l}\text { The number of } \\
\text { errors }\end{array}$ & Percent\% \\
\hline 1.Word Choice errors & $\begin{array}{l}\text { I do not want to live } \\
\text { problems. }\end{array}$ & $\begin{array}{l}\text { I do not want to } \\
\text { experience problems. }\end{array}$ & 10 & 20.83 \\
\hline 2. Wrong form errors & Live in a city is difficult. & $\begin{array}{l}\text { Living in a city is } \\
\text { difficult. }\end{array}$ & 7 & 22.92 \\
\hline 3. Collocation errors & $\begin{array}{l}\text { People have exercise less in a } \\
\text { city. }\end{array}$ & $\begin{array}{l}\text { People do exercise less in } \\
\text { a city. }\end{array}$ & 11 & 41.67 \\
\hline 4. Spelling errors & $\begin{array}{l}\text { People should protect the } \\
\text { envent. } \\
\text { environment. }\end{array}$ & 20 & \\
\hline
\end{tabular}

Lexical interference may be associated with the inability of forming semantic relationships. In order to surpass this, students need to have a good command of English. In this study, it is seen that word choice and collocation errors are based on a direct translation from L1.

\subsection{What types of grammatical errors are common in Arabic EFL students' writings?}

Table 3. Grammatical Interference Errors in Arabic EFL Students' Writings

\begin{tabular}{|c|c|c|c|c|}
\hline Grammatical Interference & Example & The correct form & $\begin{array}{l}\text { The number } \\
\text { of errors }\end{array}$ & $\begin{array}{l}\text { Percent } \\
\%\end{array}$ \\
\hline 1. Pronoun errors & $\begin{array}{l}\text { Them hobby is doing } \\
\text { shopping. }\end{array}$ & $\begin{array}{l}\text { Their hobby is } \\
\text { doing shopping. }\end{array}$ & 30 & 8.52 \\
\hline 2. Singular\&Plural Noun errors & $\begin{array}{l}\text { A person might wear } \\
\text { that clothes }\end{array}$ & $\begin{array}{l}\text { A person might } \\
\text { wear those clothes. }\end{array}$ & 20 & 5.68 \\
\hline 3. Article mistakes & $\begin{array}{l}\text { Most of students live } \\
\text { in the hostels. }\end{array}$ & $\begin{array}{l}\text { Most of the students } \\
\text { live in the hostels. }\end{array}$ & 45 & 12.78 \\
\hline 4. Countable \&Uncountable errors & $\begin{array}{l}\text { Transportation are } \\
\text { important in a city. }\end{array}$ & $\begin{array}{l}\text { Transportation is } \\
\text { important in a city. }\end{array}$ & 12 & 3.41 \\
\hline 5. Prepositions errors & $\begin{array}{l}\text { Students are addicted } \\
\text { in the Internet. }\end{array}$ & $\begin{array}{ll}\text { Students } & \text { are } \\
\text { addicted to } & \text { the } \\
\text { Internet. } & \end{array}$ & 41 & 11.65 \\
\hline 6.Adjective\&Adverb errors & $\begin{array}{l}\text { They live their life } \\
\text { fastly. }\end{array}$ & $\begin{array}{l}\text { They live their life } \\
\text { fast. }\end{array}$ & 13 & 3.69 \\
\hline 7. Tense errors & $\begin{array}{l}\text { They makes a big } \\
\text { noise yesterday. }\end{array}$ & $\begin{array}{l}\text { They make a big } \\
\text { noise. }\end{array}$ & 45 & 12.78 \\
\hline 8. Word Order errors & $\begin{array}{l}\text { Some people want to } \\
\text { do fast their job.... }\end{array}$ & $\begin{array}{l}\text { Some people want } \\
\text { to do their job fast }\end{array}$ & 7 & 1.99 \\
\hline 9. Relative Clause Errors & $\begin{array}{l}\text { People who prefer } \\
\text { online shopping they } \\
\text { can have problems. }\end{array}$ & $\begin{array}{l}\text { People who prefer } \\
\text { online shopping can } \\
\text { have problems. }\end{array}$ & 15 & 4.26 \\
\hline
\end{tabular}




\begin{tabular}{|c|c|c|c|c|}
\hline 10.Comparative\&Superlative errors & $\begin{array}{l}\text { Living in a hostel is } \\
\text { more cheaper }\end{array}$ & $\begin{array}{l}\text { Living in a hostel is } \\
\text { cheaper }\end{array}$ & 14 & 3.98 \\
\hline 11. Punctuation errors & $\begin{array}{l}\text { People want to have } \\
\text { more opportunities } \\
\text { thus, they live in } \\
\text { cities. }\end{array}$ & $\begin{array}{l}\text { People want to have } \\
\text { more opportunities, } \\
\text { thus they live in } \\
\text { cities. }\end{array}$ & 53 & 15.06 \\
\hline 12. Capitalization errors & $\begin{array}{l}\text { Students sleep late. } \\
\text { they have many } \\
\text { problems. }\end{array}$ & $\begin{array}{l}\text { Students sleep late. } \\
\text { They have many } \\
\text { problems. }\end{array}$ & 57 & 16.19 \\
\hline
\end{tabular}

The findings of table 3 are in line with Diab (1996) who analyzed 73 Lebanese native speakers of Arabic studying English at the American university of Beirut and found lexical $(n=217)$ and grammatical $(\mathrm{n}=558)$ errors made by the students due to the L1 negative interference.

\subsection{What types of lexical errors are common in Arabic EFL students' writings?}

Table 4. Lexical Interference Errors in Arabic EFL Students' Writings

\begin{tabular}{|l|l|l|l|l|}
\hline $\begin{array}{l}\text { Lexical } \\
\text { Interference }\end{array}$ & Example & The correct form & $\begin{array}{l}\text { The number of } \\
\text { errors }\end{array}$ & $\begin{array}{l}\text { Percent } \\
\%\end{array}$ \\
\hline $\begin{array}{l}\text { 1.Word } \\
\text { Choice errors }\end{array}$ & $\begin{array}{l}\text { People want to buy cheap } \\
\text { dresses. }\end{array}$ & $\begin{array}{l}\text { People want to buy cheap } \\
\text { lothes. }\end{array}$ & 15 & 15.62 \\
\hline $\begin{array}{l}\text { 2.Wrong form } \\
\text { errors }\end{array}$ & $\begin{array}{l}\text { One reason is find more } \\
\text { options. }\end{array}$ & $\begin{array}{l}\text { One reason is finding more } \\
\text { options. }\end{array}$ & 10 & 10.41 \\
\hline $\begin{array}{l}\text { 3. Collocation } \\
\text { errors }\end{array}$ & $\begin{array}{l}\text { Everyone wants to be good in } \\
\text { English. }\end{array}$ & $\begin{array}{l}\text { Everyone wants to be good } \\
\text { at English. }\end{array}$ & 13 & 13.54 \\
\hline $\begin{array}{l}\text { 4. Spelling } \\
\text { errors }\end{array}$ & Broduct & Product & 58 & 60.41 \\
\hline
\end{tabular}

Table 4 shows that Arabic students who majored in English committed lexical errors including word choice, word part, collocation, and spelling errors. SattiHamad and Yassin $(2015$, p. 68) in their study classified other lexical errors of Arabic students majoring in English in Sudan as; word choice transliteration, omission, misspelling, and redundancy. Accordingly, it can be concluded that lexical errors may vary across countries.

\subsection{What are the EFL students' overall points on grammar and lexis in the final written exam?}

Table 5. Turkish and Arabic EFL Students' average points on grammar and lexis in final writing exams papers

\begin{tabular}{|l|l|l|}
\hline Average Points & Arabic students & Turkish students \\
\hline Grammar average points .../10 & 5.9 & 6.6 \\
\hline Lexis average points .../10 & 5.6 & 7 \\
\hline
\end{tabular}


3.6. What is the comparison of Turkish and Arabic EFL students' grammatical interference in writing exam?

Table 6. Comparison of Turkish and Arabic EFL Students' Grammatical Interference in Writing Exam Papers

\begin{tabular}{|l|l|l|l|l|}
\hline & Group & $\mathrm{N}$ & Mean Rank & Sum of Ranks \\
\hline $\begin{array}{c}\text { Grammatical Interference in } \\
\text { students' writing exams }\end{array}$ & Arabic Students & 15 & 19.80 & 297.00 \\
\cline { 2 - 5 } & Turkish Students & 15 & 11.20 & 168.00 \\
\cline { 2 - 5 } & Total & 30 & & \\
\hline Mann-Whitney U & 48.000 & $\mathbf{0 0 7}$ & \\
\hline Asymp. Sig. (2-tailed &
\end{tabular}

In table 6, Turkish and Arabic students' grammatical interference exam scores were compared by the Mann-Whitney U test. When the analysis is examined, it is understood that Turkish and Arabic students' grammatical interference exam scores differ statistically ( $p<0.05$ ). In other words, Arabic students have higher number of grammatical interference errors than Turkish students.

\subsection{What is the comparison of Turkish and Arabic EFL students' lexical interference in writing exam?}

Table 7. Comparison of Turkish and Arabic EFL Students by Lexical Interference in students 'writing exam papers

\begin{tabular}{|l|l|l|l|l|}
\hline & Grup & N & Mean Rank & Sum of Ranks \\
\hline $\begin{array}{c}\text { Lexical Interference in } \\
\text { students' writing exams }\end{array}$ & Arabic Students & 15 & 18.60 & 279.00 \\
\cline { 2 - 5 } & Turkish Students & 15 & 12.40 & 186.00 \\
\cline { 2 - 5 } & Total & 30 & & \\
\hline Mann-Whitney U & 66.000 & $\mathbf{0 4 9}$ & \\
\hline Asymp. Sig. (2-tailed &
\end{tabular}

In table 7, it is seen that Turkish and Arabic students' lexical interference exam scores are compared by the Mann-Whitney $U$ test. When the analysis is examined, it is understood that Turkish and Arabic students' lexical interference exam scores differ statistically ( $\mathrm{p}<0.05)$. In other words, Arabic students have higher lexical interference errors than Turkish students.

The purpose of this study was to identify Turkish and Arabic students' grammatical and lexical interference errors in their writing assignments. When the students' written exams are analyzed, it can be concluded that Turkish and Arabic students commit a high number of interference errors both in grammar and lexis. When Arabic and Turkish students' average points are compared, Turkish students achieved higher than Arabic students although there was no dramatic difference between the two groups of students. While Arabic students got 5.9 out of 10 on average, Turkish students got 6.6. In the lexis part, the difference between the two groups was higher than the grammar part. While Arabic students had 5.6 out of 10 on average, Turkish students achieved 7 . 
When the total amount of errors is analyzed, Arabic students have 352 grammar errors in the grammar part, whilst Turkish students have 164 grammar errors. Arabic students make a huge part of errors in capitalization, punctuation, and tenses; respectively as $16.19 \%, 15.06 \%$, and $12.78 \%$. The reason why they make the majority of their errors on capitalization and punctuation is that Arabic and English have negative interference in terms of the writing systems. As Sofer and Raimes (2002) have stated due to the absence of capitalization rules in the Arabic language, students may lack capitalization rules in their writings such as the first letter at the beginning of a sentence, names of countries, people, places, and nationalities. There is also no difference between upper and lower case letters in Arabic. In terms of the use of tenses, Arabic and English have major differences, as well. As cited in Sabbah (2015), Aoun Benmamoun, and Chueiri state that there are two types of tenses in Arabic. One is called the perfect (only the past) and the other one is called the imperfect (the non-past, simple present, and simple future). Due to differences in terms of tenses, Arabic students make many errors in using the correct tense"' (p. 277).

In terms of lexis, Arabic students make 96 errors in total, the majority of which are spelling errors. $60.4 \%$ of the mistakes are on spelling while $15.5 \%$ of the errors are wrong word choice. Many of the studies carried by EFL Arabic language learners confirm that spelling mistakes make up the majority of errors in lexis. For instance, according to Altamimi et al "among the various difficulties faced by Arab learners learning English, the most common error is related to the spelling of words used in documents" (2018, p. 2). According to Jayousi and Thaher (2011), the students in the United Arab Emirates experienced a lot of spelling problems in their writing and this affected their language ability and success at school negatively.

When it comes to Turkish B1 students, they make 164 grammar errors in total, the majority of which are articles, preposition, and tense errors respectively as $18.82 \%, 17.65 \%$, and $11.76 \%$. Most of the Turkish students make article mistakes in their writing assignments because there is no definite article "the" in Turkish as Kesmez (2014) confirms in his study on L1 interference on Turkish university students' written productions. Elkılıç as cited in Kesmez (2014) puts forward that "prepositions aren't used as separate grammatical items in Turkish. On the contrary, they are added to the endings of the nouns to show whether they are accusative, dative, or genitive" (p. 2). The fact that there are differences in terms of the use of tenses in both languages Turkish students make many errors in their writings such as wrong use of -ed or irregular verbs in Simple Past Tense and wrong use of Present Perfect Tense.

Turkish students committed 48 lexical errors, the majority of which are spelling and collocation errors. As Turkish words are spelled as they are spoken, Turkish learners can go through some difficulties in the spelling of English words. According to Kocatepe as cited in Altamimi et al, "the patterns of an individual's first language become part of the linguistic instinct of that individual" (2018, p. 88). Therefore, Turkish students may make these spelling errors with the effect of their mother tongue.

\section{Discussion}

The main purpose of the present study was to investigate the processes of foreign language learning, first language maintenance, and language transfer in the case of the Turkish and Arabic EFL students studying English at higher education in Turkey, as well as the effect of L1 on the second language.

The contrastive analysis has been used mainly for the comparison of two languages. In this study, it has been concluded that L1 interference is the most underlying reason for student errors. This finding is in contrast with the study of Can (2018), which compared the error typologies of Turkish and Greek EFL learners and found that intra-lingual errors resulted from faulty or partial learning of the target language rather than mother-tongue interference. In this study, it has been concluded that common cause 
for the lexical errors stems from L1 interference which is in line with the study of Kirmizi and Karci (2017). When we consider the L1 of the participants of the study it may be concluded that Turkish and Arabic have unique linguistic characteristics that make them distinctive. Besides, these languages belong to totally different language families. However, as can be seen from the findings, both Turkish and Arabic students display similar types of errors. In this frame, it may be concluded that students whose L1 is different, share something in common when it comes to learning a new language. The findings of this study revealed that lexical errors mostly resulted from spelling errors for both Turkish and Arabic students. Besides, collocation errors were problematic for Turkish EFL students, whilst word choice errors were the second most committed type of error for Arabic EFL learners. When the errors of Arabic and Turkish students are examined, it can be stated that the most problematic part in grammar for both groups might stem from L1 interference as Arabic students struggle with capitalization and Turkish students find it hard to use articles correctly.

\section{Conclusion}

In the lexis part, it is concluded that both Turkish and Arabic students make spelling mistakes, the reason for which can be interpreted as L1 interference errors. It can also be stated that both groups learn L2 within the effect of their mother tongue. There can be many other factors given for writing errors such as using bilingual dictionaries, using direct translation methods, or having poor language skills.

As EFL teachers, we are more likely to have students from different cultural backgrounds with different languages. Therefore, it is up to teachers to guide learners in their language learning process. Students should be exposed to target language more in-class time and students should be given more opportunities to produce in the target language. Teachers should also be aware of students' background and thus they should know that some errors may stem from students' first language. Therefore, teachers as facilitators should be more tolerant and patient in students' language learning process. Being aware of students' L1 interference errors, teachers can design the lessons more in line with their students' needs. By having a needs analysis, teachers can adapt their lesson plans, materials, and activities to diminish L1 errors.

\section{Ethics Committee Approval}

The author(s) confirm(s) that the study does not need ethics committee approval according to the research integrity rules in their country (Date of Confirmation: August 18, 2020).

\section{References}

Ali, N. (2007). Some linguistic problems facing Arab learners of English. Adab Alrafidayn, (48), 1-14. Retrieved from http://www.iasj.net/iasj?func=fulltext\&aId=33586.

Altamimi, D. A. H. F., Ab Rashid, R., \& Elhassan, Y. M. M. (2018). A Review of Spelling Errors in Arabic and Non-Arabic Contexts. English Language Teaching, 11(10), 88-94.

Brown, H. D. (2007). Principles of language learning and teaching. (4th ed.). New York: Longman.

Burt, M. K. (1975). Error analysis in the adult EFL classroom. TESOL Quarterly, 9(1), 53-63. 
Can, C. (2018). Agreement errors in learner corpora across CEFR: A computer-aided error analysis of Greek and Turkish EFL learners written production, Journal of Education and Training Studies, 6, 77-84.

Diab, N. (1996). The transfer of Arabic in the English writings of Lebanese students, The ESP, São Paulo, 18(1), 71-83.

Ehri, L. C., \& Rosenthal, J. (2010). Spellings of words: A neglected facilitator of vocabulary learning. In Literacy Development and Enhancement Across Orthographies and Cultures (pp. 137- 152). Boston, MA. Springer; 10.1007/978-1-4419-0834-6_10.

Elk1liç, G. (2012). Mother tongue traces of Turkish university students on composition papers written in English. Procedia-Social and Behavioral Sciences, 47, 656-664.

Ellis, R. (1997). Second language acquisition. Oxford University Press: Oxford.

Ellis, N. (2006). Selective attention and transfer phenomena in L2 acquisition: Contingency, cue competition, salience, interference, overshadowing, blocking, and perceptual learning. Applied Linguistics, 27(2),164-194, Oxford University Press.

Erkaya, O. R. (2012). Vocabulary and L1 interference-error analysis of Turkish students' English essays. Mextesol Journal, 36(2), 1-11.

Gass, S. M. \& Selinker, L. (2008). Second language acquisition: An introductory course. New York, NY: Routledge.

Hamdallah, R., \&Tushyeh, H. (1993). A contrastive analysis of selected English and Arabic prepositions with pedagogical implications, 181-190. Nablus, West Bank: An-Najah National University. Retrieved from: http://ifa.amu.edu.pl/psicl/files/28/11Hamdallah \&Tusyehh.pdf

Jayousi, A., \& Thaher, M. (2011). Spelling errors of Arab students: Types, causes, and teachers' responses (Doctoral dissertation).

Jie, X. (2008). Error theories and second language acquisition. US-China foreign language, 6(1), 3542.

Johansson, S. (2008). Contrastive analysis and learner language: A corpus-based approach. Oslo: University of Oslo.

Kesmez, A. (2014). An analysis of the L1 interference errors of Turkish university students in their written productions. The Journal of Academic Social Science Studies, 34(28), 395-402.

Kirmızı, O., \& Karci, B. (2017). An Investigation of Turkish Higher Education EFL Learners' Linguistic and Lexical Errors. Educational Process: International Journal, 6(4), 35-54.

Kırkgöz, Y. (2010). An analysis of written errors of Turkish adult learners of English. Procedia- Social and Behavioral Sciences, 2(2), 4352-4358.

Köroğlu, Z. (2014). An analysis on grammatical errors of Turkish EFL studentse written texts. International Periodical for the Languages, Literature and History of Turkish, 9(12), 101-111. Retrieved from http://turkishstudies.net/Makaleler/374851580_8\%c3\%87etinK

Nunan, D. (2001). Second language acquisition. In R. Carter \& D., Nunan (Eds.), The Cambridge guide to teaching English to speakers of other languages [C]. (pp. 87- 92). Cambridge: Cambridge University Press. 
Özer, M. (2016). The internationalization of higher education in Turkey: Realities, motivations and opportunities. Insight Turkey, 18(4), 53-64.

Pierce, D. (2009). The logic of Turkish. Retrieved from: http://mat.msgsu.edu.tr/ dpierce /Language/Turkish/Logic/logic.pdf

Richards, J., \& Schmidt, R. (2002). Dictionary of language teaching \& applied linguistics. Pearson Education Limited. London: Longman.

Rohmah, I. I. T. (2017). Classroom interaction in English language class for students of economics education. Arab World English Journal, 8(2), 192-207.

Sabbah, S. (2015). Negative transfer: Arabic language interference to learning English. Arab World English Journal (AWEJ), Special Issue on Translation, (4), 269-288.

SattiHamad, M., \& Yassin, A. (2015). Investigating lexical errors and their effect on university students' written performance in Sudan. SUST Journal of Humanities, 16(1) 1-18.

Sofer, N. Z., \& Raimes, A. (2002). Keys for writers. A brief handbook, (3rd ed.). Houghton Mifflin Company.

Taşçı, S., \& Aksu Ataç, B. (2018). İngilizce Öğrenen Yetişkin Türk Öğrencilerin Yazılı Dilbilgisi Hatalarının Bir Analizi. Uluslararası Sosyal Bilimler Eğitimi Dergisi, 4(1), 1-13. Retrieved from https://dergipark.org.tr/tr/pub/issej/issue/37517/348530 


\section{Anadilden aktarım yanlışlarının yabancı dilde yazmaya etkisi: Karşıtsal yanlış çözümlemesi}

\section{Öz}

Günümüz dünyasında, eğitim ortamları her geçen gün çok kültürlü hale gelmektedir. Türkiye'de EFL (Yabancı dil olarak İngilizce) sınıfları on yıl önce çoğunlukla Türk öğrencilerden oluşmakta iken, bugün dünyanın her yerinden öğrenciler çeşitli öğrenci değişim programları çerçevesinde bir araya gelebilmektedir. Türk EFL bağlamında, Orta Doğu ülkelerinden gelen öğrenciler söz konusu potansiyelin büyük bir bölümünü oluşturmaktadır (Özer, 2016). Bu çalışma, Türk ve Arap EFL öğrencilerinin L1 'olumsuz aktarım' hatalarını bulmayı amaçlamaktadır. Buna göre; Dilbilgisi ve Sözcük Seçimi kategorilerinde 30 B1 (Orta) seviye öğrencinin yazılı ödevi analiz edilmiştir. Bu ödevlerin 15'i Türk; 15'i ise Arap EFL öğrenciler tarafindan yazılmıştır. Bu anlamda çalışma, Türkçe ve Arap EFL öğrencilerinin hatalarının olumsuz aktarım çerçevesinde karşılaştırmalı bir analizini de içermektedir. MannWhitney U testi sonuçları incelendiğinde, Türk ve Arap öğrencilerin dilbilgisel aktarım yanlışlarından aldıkları puanların istatistiksel olarak farklı olduğu anlaşılmaktadır $(\mathrm{p}<0.05)$. Diğer bir deyişle, Arap öğrencilerin dilbilgisel aktarım yanlışına iliş̧kin sınav puanları, Türk öğrencilerden daha yüksektir. Toplam hata miktarı analiz edildiğinde, Türk öğrencilerin dilbilgisi hatalarının ( $\mathrm{n}=164)$ çoğunluğu tanımlık, edat ve zaman hataları (\%18.82, \%17.65 ve \%11.76) iken, Arap öğrencilerin hatalarının büyük bir bölümünü ( $n=352$ ) sırasıyla; büyük harf, noktalama, zaman yanlışları ve tanımlık (\%16.19,\%15.06, \%12.78) oluşturmaktadır. Sözcük kategorisi çerçevesinde, Türk öğrenciler çoğunluğu yazım ve eşdizimlik hatalarından oluşan 48 sözcük hatası yapmıştır. Öte yandan, Arap öğrenciler toplamda 96 sözcük hatası yapmış, bunların çoğunu yazım yanlışları (\%60.4) ve yanlış kelime seçimi (\%15.5) oluşturmuş̧ur. Genel olarak, sözcüksel hataların gramer hatalarından daha az olduğu belirlenmiştir.

Anahtar sözcükler: anadilden aktarım; karşılaştırmalı hata analizi; yabancı dil olarak ingilizce öğrenen Türk ögrenciler; yabancı dil olarak ingilizce öğrenen Arap öğrenciler; uygulamalı dilbilim

\section{AUTHOR BIODATA}

Dr. Semin KAZAZOĞLU, holds a B.A. in English Language and Literature (2000), an M.A. (2006) and Ph.D. (2011) in Foreign Language Teaching from Ankara University. She currently works as an assistant professor in the department of English Language Education at Yıldız Technical University. She studied a suggested reading syllabus for $\mathrm{C} 1$ (effective operational proficiency) level defined in CEFR for her M.A. thesis. Her research and publications focus on EFL learners' reading and writing skills, applied linguistics, and foreign language education. 